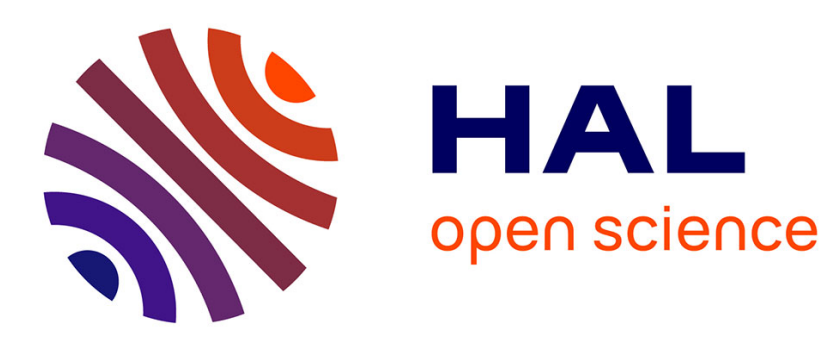

\title{
Language and identity construction on the French Guiana-Suriname border
}

Isabelle Léglise, Bettina Migge

\section{To cite this version:}

Isabelle Léglise, Bettina Migge. Language and identity construction on the French Guiana-Suriname border. International Journal of Multilingualism, 2019, pp.1-15. 10.1080/14790718.2019.1633332 . hal-02182399

\section{HAL Id: hal-02182399 \\ https://hal.science/hal-02182399}

Submitted on 25 Oct 2019

HAL is a multi-disciplinary open access archive for the deposit and dissemination of scientific research documents, whether they are published or not. The documents may come from teaching and research institutions in France or abroad, or from public or private research centers.
L'archive ouverte pluridisciplinaire HAL, est destinée au dépôt et à la diffusion de documents scientifiques de niveau recherche, publiés ou non, émanant des établissements d'enseignement et de recherche français ou étrangers, des laboratoires publics ou privés. 
Isabelle Léglise \& Bettina Migge (2019): Language and identity construction on the French Guiana-Suriname border, International Journal of Multilingualism,

DOI:10.1080/14790718.2019.1633332

\section{Language and identity construction on the French Guiana-Suriname}

\section{border}

\section{Isabelle Léglise ${ }^{\mathrm{a} *}$ and Bettina Migge ${ }^{\mathrm{b}}$}

${ }^{a}$ SeDyL CNRS, Paris, France; ${ }^{b}$ School of Languages, Cultures \& Linguistics, University College Dublin, Dublin, Ireland

*corresponding author

Isabelle LEGLISE

CNRS SeDyL

7, rue Guy Môquet

94800 Villejuif

FRANCE

\section{Isabelle.leglise@cnrs.fr}

Isabelle Léglise is a senior researcher in Linguistics at the French National Centre for Scientific Research (CNRS, Paris) where she heads the SeDyL (Structure et Dynamique des Langues) Research Center. The last 20 years, she has been engaged in research projects and scientific cooperation in French Guiana, Suriname and Brazil with a special focus on multilingualism, migration and educational issues. She has published widely on language variation and language contact, translanguaging and heterogeneous corpora, discourse analysis and language policy related to education and health. ORCID: 0000-0002-2415-4173

Bettina Migge is Professor of Linguistics at University College Dublin. She previously worked at Johann-Wolfgang Goethe Universität, Frankfurt am Main and studied at Universität Hamburg, Université de Yaoundé, Freie Universität Berlin and at the Ohio State University. Her research deals with sociolinguistics, language contact, language description, language and migration and education with an empirical focus on French Guiana, Suriname and Ireland.

ORCID: 0000-0002-3305-7113 
Isabelle Léglise \& Bettina Migge (2019): Language and identity construction on the French Guiana-Suriname border, International Journal of Multilingualism, DOI:10.1080/14790718.2019.1633332

\section{Language and identity construction on the French Guiana-Suriname border $^{1}$}

On the French Guiana-Suriname border, a hybrid space, members of the same population groups engage in circular mobility but little is known about the practices of these transnational communities. We explore how traditional emic social distinctions, modern states' language ideologies and emerging discourses in the urban context shape Maroon's practices and identities in the border zone. A survey of language repertoires and long-term ethnographic fieldwork, including recordings of situated multilingual interactions, allow us to explore people's alignment with national language ideologies and the nature of distinctive ideologies, identifications and practices that can be observed in the border zone. We show that the border zone constitutes a separate sociolinguistic area, in terms of both language use and ideologies. However, similarities do not preclude sharp differences at other levels because multiple identifications co-exist. The findings support a layered and dynamic perspective of identity and illustrate how contradictory perspectives simultaneously overlap on one or several scales.

Keywords: spatial and symbolic borders; transnationalism; Suriname; French Guiana; multilingualism; language ideology

\section{Introduction}

The Guyana Plateau in Northern South America is a hybrid social space due to historical and recent cross-regional migration, forced population movements under slavery and indentured labour schemes during colonial times. The same or closely related population groups and languages are now part of two or more modern nation

\footnotetext{
${ }^{1}$ This paper is dedicated to the memory of Misty Jaffe who generously helped us improve a first draft of this paper but wasn't able to see the final version.
} 
Isabelle Léglise \& Bettina Migge (2019): Language and identity construction on the French Guiana-Suriname border, International Journal of Multilingualism, DOI:10.1080/14790718.2019.1633332

states, often straddling the borders of these states. This raises the question of the effects of national borders on language and identity in such transnational contexts and in the border area where national norms and conceptualisations may be weaker (Llamas 2010). Linguistics traditionally implicitly assumes that geographical boundaries, national borders and languages overlap (e.g., see dialectological maps). According to Urcioli (1995: 527) '[t]he genesis of the notion of language and borders lies in the shared "imagining" (Anderson 1983) of spatially bounded, linguistically homogenous nations.' Research on language and borders critically examines this assumption, investigating whether 'languages cause borders or borders cause languages' (Busch \& Kelly-Holmes 2004: 1). While there tends to be a close fit between political borders, cultural boundaries and socio-economic borders in the case of nation states (Balibar 1997: 397), the state's role in determining language, cultural and social practices and political alignments is questionable in borderlands. National borders are also social, political and discursive constructs (Newman \& Paasi 1998). Key questions in border studies therefore are: how can we conceptualise borders and boundaries in a cosmopolitan and mobile world? How do these conceptualisations affect social, linguistic and metalinguistic practices and identification (Omoniyi 2004)? What role do language practices play in constructing boundaries (Greco \& Auzanneau 2018)? To what extent are border areas distinct sociolinguistic areas and how do they relate to the respective nation states?

This paper addresses the final issue of whether or not and in what sense the French Guiana-Suriname border zone constitutes a separate sociolinguistic area -in terms of both language use and language ideologies. To answer this question, we explore people's alignment with national language ideologies and the nature of 
Isabelle Léglise \& Bettina Migge (2019): Language and identity construction on the French Guiana-Suriname border, International Journal of Multilingualism, DOI:10.1080/14790718.2019.1633332

distinctive ideologies, identifications and practices that can be observed in the border zone. The evidence suggests that the Suriname-French Guiana border region constitutes a separate sociolinguistic area although it is not completely (linguistically) distinct from the two nation states as the influence of both nation states' ideologies is still tangible in the border zone.

Research traditionally either relies on qualitative interview or on largely quantitative survey data (Omoniyi 2004) instead of triangulating both types of data and therefore either pursues a macro or micro perspective. This study combines the analysis of language ideologies and language naming practices from a survey with long-term participant observation and the analysis of heterogeneous language practices in recorded interactions to obtain micro and macro level insights.

Irvine (1989: 255) defines language ideologies as a 'cultural system of ideas about social and linguistic relationships, together with their loading of moral and political interests', suggesting that they link the use of languages in interactions (language practices), metalinguistic comments on ways of using languages and naming, for instance, to the understanding of social entities such as national or ethnic identities or communities, gender grouping etc. These relationships are variable over time and across society(s) but 'may become temporarily iconicized whereby a linguistic feature comes to somehow depict 'a social group's inherent nature or essence. [...] in a linkage that appears to be inherent' erasing evidence to the contrary (Irvine and Gal 2000: 37-38). Research has examined the nature of language ideologies and their role in maintaining minority languages, including multilingualism and revitalisation efforts (Austin \& Sallabanks 2014), employing discourse-based qualitative methods of analysis. 
Isabelle Léglise \& Bettina Migge (2019): Language and identity construction on the French Guiana-Suriname border, International Journal of Multilingualism, DOI:10.1080/14790718.2019.1633332

Identity and its relationship to language is widely discussed in sociolinguistics and linguistic anthropology (Preece 2016 among others). Bucholtz \& Hall (2010) argue that identity is a person's sense of (temporary) alignment with specific social positions or ideologies, groupings, places etc. including those assigned by others. Identity construction then are the ways in which people negotiate and renegotiate these positions in interactions through processes of identification and differentiation involving creating temporary affiliations, alignments, or dis-alignments. Research in this area has focused on how people draw on specific linguistic phenomena and processes such as indexicality (Ochs 1992), iconisation (Irvine \& Gal 2000), stance (Jaffe 2009) or enregisterment (Agha 2005) in order to construct identity positions or embody social entities using qualitative and recently also quantitative sociolinguistic methods (Eckert 2018).

Section two presents the sociolinguistic context of the two nations and the border zone, and section three sets out the methodology. Evidence in favour of the continued salience of national language ideologies and their impact in the border zone are explored in section four and section five examines alternative language and identity indexicalities.

\section{French Guiana, Suriname, the Maroons and the border zone}

Suriname and French Guiana share a common border and also border on Brazil and the Republic of Guyana (Suriname). French Guiana (Guyane Française) is the largest French overseas region and is subject to the same laws and regulations as metropolitan France. Suriname became independent from the Netherlands in 1975 and is the smallest sovereign state in South America. The majority of their populations live along the relatively urbanised coastal strip. Small population concentrations are situated in 
Isabelle Léglise \& Bettina Migge (2019): Language and identity construction on the French Guiana-Suriname border, International Journal of Multilingualism,

DOI:10.1080/14790718.2019.1633332

primary rainforest along major rivers such as the Maroni/Marowijne River and its tributaries, the Suriname, Saramacca and Nikerie Rivers (Suriname) and the Oyapock River (French Guiana). Suriname's population is estimated at 547000 (2016) and that of French Guiana at a mere 250,400 (2014).

Both political constituencies have a similar macro-linguistic makeup - an excolonial language coexists with several local languages, see Tables 1 and 2.

Table 1: Languages spoken in Suriname (Migge \& Léglise 2015: 82)

\begin{tabular}{|c|c|c|c|c|}
\hline $\begin{array}{l}\text { Official } \\
\text { language }\end{array}$ & $\begin{array}{l}\text { Amerindian } \\
\text { languages }\end{array}$ & Creole languages & Asian languages & 'Newer Arrivals' \\
\hline Dutch & $\begin{array}{l}\text { Kari'na } \\
\text { Trio } \\
\text { Arawak/Lokono } \\
\text { Wayana }\end{array}$ & $\begin{array}{l}\left.\begin{array}{l}\text { Aluku } \\
\text { Ndyuka or } \\
\text { Pamaka }\end{array}\right] \text { Aukaans } \\
\text { Kwinti } \\
\text { Matawai } \\
\text { Saamaka } \\
\text { Sranantongo }\end{array}$ & $\begin{array}{l}\text { Sarnámi } \\
\text { Javanese } \\
\text { Varieties of Chinese }\end{array}$ & $\begin{array}{l}\text { Brazilian Portuguese } \\
\text { Guyanese English or } \\
\text { Guyanese Creole } \\
\text { Haitian Creole } \\
\text { Varieties of Chinese }\end{array}$ \\
\hline
\end{tabular}

Table X: Languages spoken in French Guiana (Migge \& Léglise 2015: 83)

\begin{tabular}{|l|l|l|l|l|}
\hline $\begin{array}{l}\text { Official } \\
\text { language }\end{array}$ & $\begin{array}{l}\text { Amerindian } \\
\text { languages }\end{array}$ & French Creoles & $\begin{array}{l}\text { English } \\
\text { Creoles }\end{array}$ & 'Newer Arrivals' \\
\hline French & Kali'na & Fr. Guianese Creole & Aluku & Hmong \\
& Arawak/Lokono & Martiniquan & Ndyuka & varieties of Chinese \\
& Wayana & Guadeloupean & Pamaka & Brazilian Portuguese \\
& Emerillon/Teko & St. Lucian & Saamaka & Haitian Creole \\
& Palikur & Sranantongo & $\begin{array}{l}\text { Guyanese English or } \\
\text { Creole }\end{array}$ \\
& Wayãpí & & & \\
\hline
\end{tabular}


Isabelle Léglise \& Bettina Migge (2019): Language and identity construction on the French Guiana-Suriname border, International Journal of Multilingualism, DOI:10.1080/14790718.2019.1633332

The Suriname-French Guiana border area includes the French Guianese town of Saint-Laurent-du-Maroni (around 40,500 inhabitants), the Surinamese town of Albina (roughly 5,300 inhabitants in 2012) and the up-river region extending to the rapidly urbanising village of Apatou (see Map 1). Although connected by a mere ten-minute boat ride, access to the two countries is officially governed by strict visa regulations. In practice, however, people regularly spend shorter or longer periods of time for personal, social, commercial reasons in the respective other country without following official procedures. Despite occasional attempts to stop illicit movement of people and goods across the border, mobility is relatively undisrupted.

This cross-border space constitutes an 'interface border' (Renard \& Picouet 2007), linking a region (French Guiana) belonging to a country from the North (France) without being really northern to one belonging to a country from the global South (Suriname), and traditional small communities and associated rural life-styles (up-river) to national societies and urbanised life-styles. Despite economic differences this border region is a maximal borderland because of frequent interactions and close socio-cultural ties between their inhabitants (Momoh 1989: 52 cited in Omoniyi 2004: 18-19). 
Isabelle Léglise \& Bettina Migge (2019): Language and identity construction on the French Guiana-Suriname border, International Journal of Multilingualism,

DOI:10.1080/14790718.2019.1633332

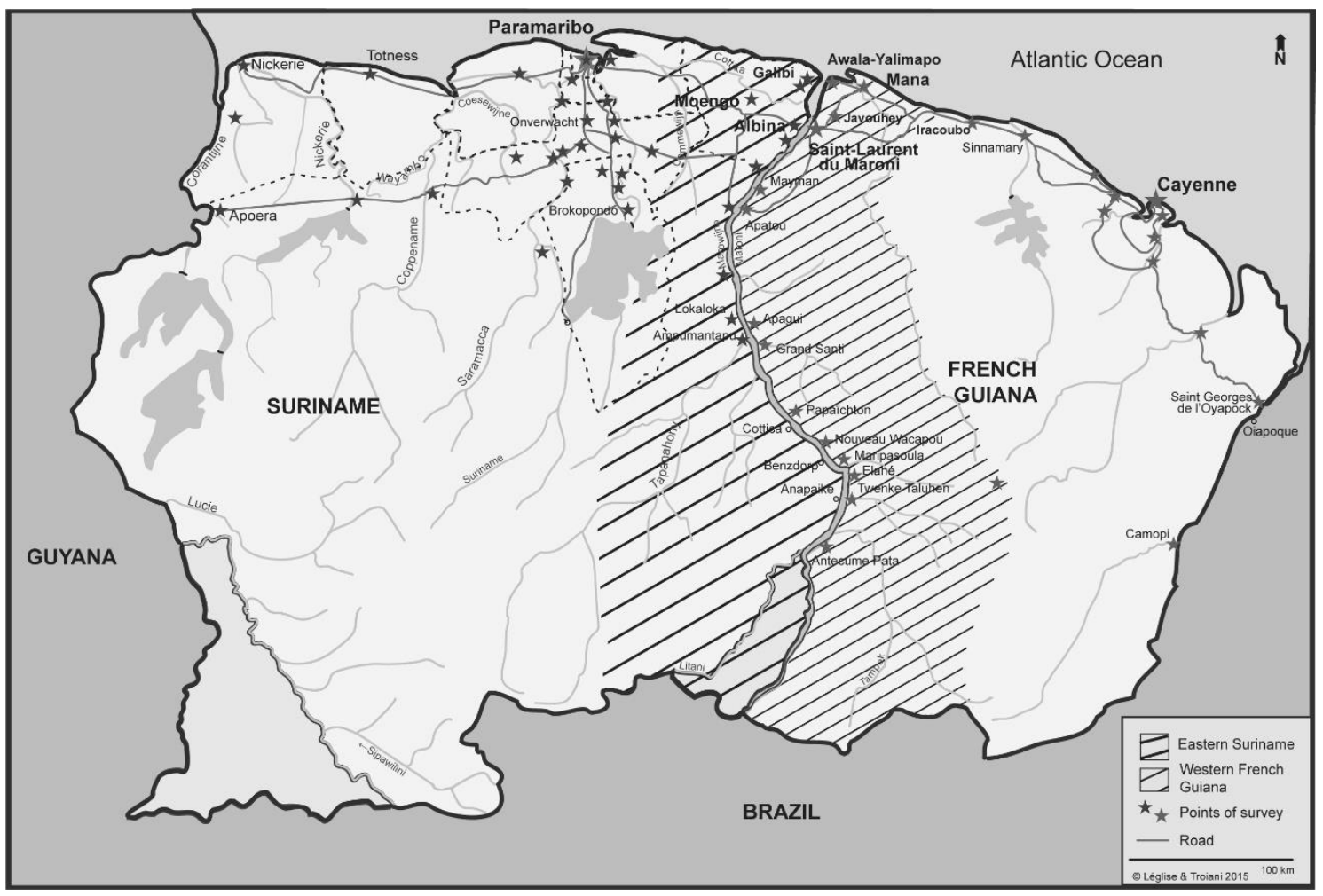

Map 1: Survey locations in French Guiana and Suriname

Although both countries have linguistically heterogeneous populations (Table $1 \&$ 2), Maroon populations dominate in the border region. They are African-American communities that emerged during the late $17^{\text {th }}$ and mid $18^{\text {th }}$ century due to their founders' flight from Dutch sugar plantations. At present, there are six Maroon communities $^{2}$ : the closely related Eastern Maroon (Aluku, Ndyuka and Pamaka), Kwinti and two Western Maroon communities (Matawai and Saamaka). They constitute around $70 \%$ on the French side and $80 \%$ on the Surinamese side of the border (see also Price 2018).

${ }^{2}$ Hoogbergen (1990) summarises their history, Price and Price (2003) and Van Stipriaan (2015) also provide information on the contemporary situation of Maroons and Migge \& Léglise (2015) assess the current sociolinguistic context. 
Isabelle Léglise \& Bettina Migge (2019): Language and identity construction on the French Guiana-Suriname border, International Journal of Multilingualism, DOI:10.1080/14790718.2019.1633332

\section{Processes of identification, data and methods}

Focusing on (Eastern) Maroons, we investigate how people are influenced by local traditional emic or national language ideologies. Firstly, we examine metalinguistic practices such as language names and labels as acts of social classification that contribute to the making and unmaking of groups (Bourdieu 1991; Joseph 2004). Secondly, we investigate how language practices construct identities or boundaries between groups (Bucholz \& Hall 2010) through processes of identification and differentiation. They provide excellent lenses for exploring the processes that sustain and dismantle existing identities and play a role in constructing new identities.

Various methods were used to document the multilingual contexts, language practices, naming and ideologies in French Guiana and Suriname. Data come from a large-scale sociolinguistic survey - data were collected in all the border zone's schools including villages and towns (St Laurent du Maroni, Mana, Moengo and Albina) - and from long-term ethnographic fieldwork in the region (Migge \& Léglise 2013) including recordings of situated interactions. In this paper, we draw on these data 1) to investigate children's metalinguistic evaluations and self-descriptions in the survey interviews and the social and language labels they used for identification,

2) to compare the survey results for the border area with those obtained for the two national contexts and with previous publications on language and culture in Suriname and French Guiana, and

3) to analyse language practices in the (two parts of the) border zone to see if they are unique and constitute evidence for a distinct sociolinguistic area.

The methodology for the sociolinguistic survey is discussed in detail in previous publications (Léglise 2007) and the results for the 28 villages and 80 schools in French 
Isabelle Léglise \& Bettina Migge (2019): Language and identity construction on the French Guiana-Suriname border, International Journal of Multilingualism, DOI:10.1080/14790718.2019.1633332

Guiana can be accessed electronically. ${ }^{3}$ The data collection process and results for Suriname are also available (Léglise \& Migge 2015). Only some of the results for the border region are discussed in the next section. The sociolinguistic survey data provide quantitative information about the nature of children's linguistic repertoires (section 4) and qualitative insights into children's ideologies (section 5).

\section{The border zone and national language ideologies}

National language ideologies in a postcolonial setting such as a French overseas' region and a newly independent state such as Suriname are unlikely to be the same. France, a prime example of a state with a strong monolingual official language ideology, promoted a policy of frenchification in its ex-colonies. The educational language policy devised in Paris continues to promote French as the sole language even though the experimental instrumentisation of local languages in education has been ongoing in French Guiana's primary school education sector for over thirty years (Léglise 2017). Officially promoted ideologies (i.e. indexical processes and dominant beliefs among the middle and upper class) identify French with metropolitan Frenchness, modern life and job opportunities. The use of French nevertheless remains socially limited in French Guiana. $75 \%$ of the children do not speak French before entering school and although competence in the official language is gradually growing (Léglise 2007), local languages such as French Guianese Creole and Amerindian and Maroon languages play an important role as primary means of self-identifications and local integration (Jolivet 2007), and are widely used monolingually or as part of multilingual repertoires.

\footnotetext{
${ }^{3}$ https://www.vjf.cnrs.fr/sedyl/Isabelle_Léglise/guyane/
} 
Isabelle Léglise \& Bettina Migge (2019): Language and identity construction on the French Guiana-Suriname border, International Journal of Multilingualism, DOI:10.1080/14790718.2019.1633332

Suriname's dual language policy with Dutch, the ex-colonial and official language, and Sranantongo, the national and former plantation language, is a legacy of colonial times (Carlin 2001: 220). There are periodically discussions to replace Dutch with English but because it is also the primary language of the Surinamese elite and continues to perform important gate-keeping functions this is not likely to happen (Carlin ibid: 238). ${ }^{4}$ Since independence, (Surinamese) Dutch has come to be officially linked to a popular national identity associated with modernity and social progress. Processes of linguistic indigenisation have also furthered its social expansion and 'give[n] it the trappings of an ethnically neutral language' (Stell 2018: 48). Sranantongo is the language of authenticity that is antithetical to modern Surinameseness and is associated with lack of deference and solidarity (Stell ibid: 52). The other languages of Suriname (see Table 1) do not have an official status and are associated with ethnically defined communities that emerged during colonial times (Carlin et al. 2015) and still confer ethnic belonging. They often have connotations of being traditional or backward, especially if used monolingually (Stell ibid: 49). Dutch and Sranantongo are encroaching on the domains of use of local languages and Dutch on those of Sranantongo (Yakpo et al 2015).

The quantitative results from our school surveys provide some evidence of the impact of national language ideologies. In both political constituencies the ex-colonial languages have a lower profile in the border zone than in the country as a whole. Dutch is declared $63 \%$ as a language of first socialisation in all of Suriname but was only cited by $40 \%$ of children in the border zone (respectively, $35 \%$ in Albina and $40 \%$ in

\footnotetext{
${ }^{4}$ In practice, though, English is rising in importance as a gate-keeper for social upward mobility.
} 
Isabelle Léglise \& Bettina Migge (2019): Language and identity construction on the French Guiana-Suriname border, International Journal of Multilingualism, DOI:10.1080/14790718.2019.1633332

Moengo, see Figure 2). Since this figure is higher than that for French on the French Guianese side this suggests that the Surinamese state's active promotion of Dutch as an icon of a modern Surinamese identity has indeed led to its greater use and family transmission.

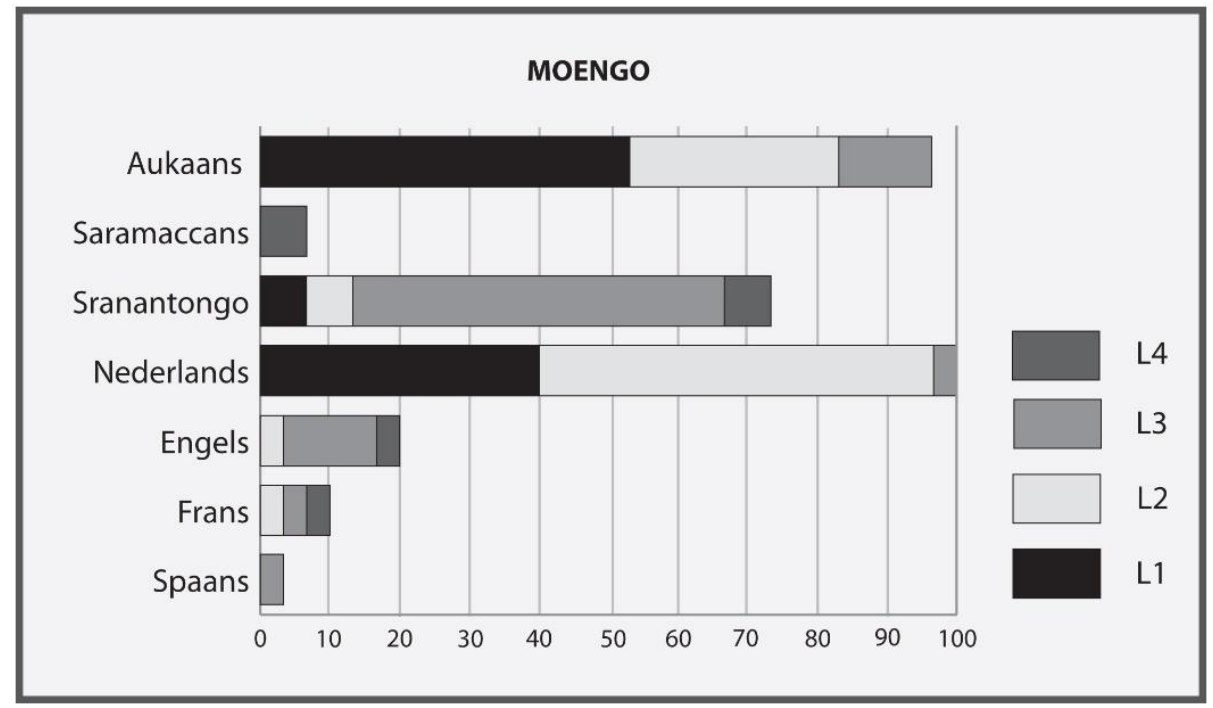

Figure 2: Languages reported in children's repertoires (results for Moengo, Suriname)

The situation is more heterogeneous in the French part of the border zone. The link between French and a French (Guianese) identity appears to be particularly weak along the Maroni River and in Saint-Laurent-du-Maroni. In this important urban area, French is declared as a language of primary socialisation by only $16 \%$ of children. In Mana (see Figure 3) this figure rises to 35\%, comparing favourably with the results for all of French Guiana (30\%). Léglise (2005) argues that the figures for Mana are due to the greater desire among many children of French Guianese Creole descent to assert identification with French Guianese coastal society. This identity-based motivation in favour of French is also indirectly confirmed by children's rejection of Sranantongo, the language iconically linked to Suriname. Sometimes, a pro-French family language 
Isabelle Léglise \& Bettina Migge (2019): Language and identity construction on the French Guiana-Suriname border, International Journal of Multilingualism, DOI:10.1080/14790718.2019.1633332

policy might also be the reason as in the case of an eleven-year-old adolescent who reported that 'my mum says we must not speak Ndyuka at home in order to better speak French'.

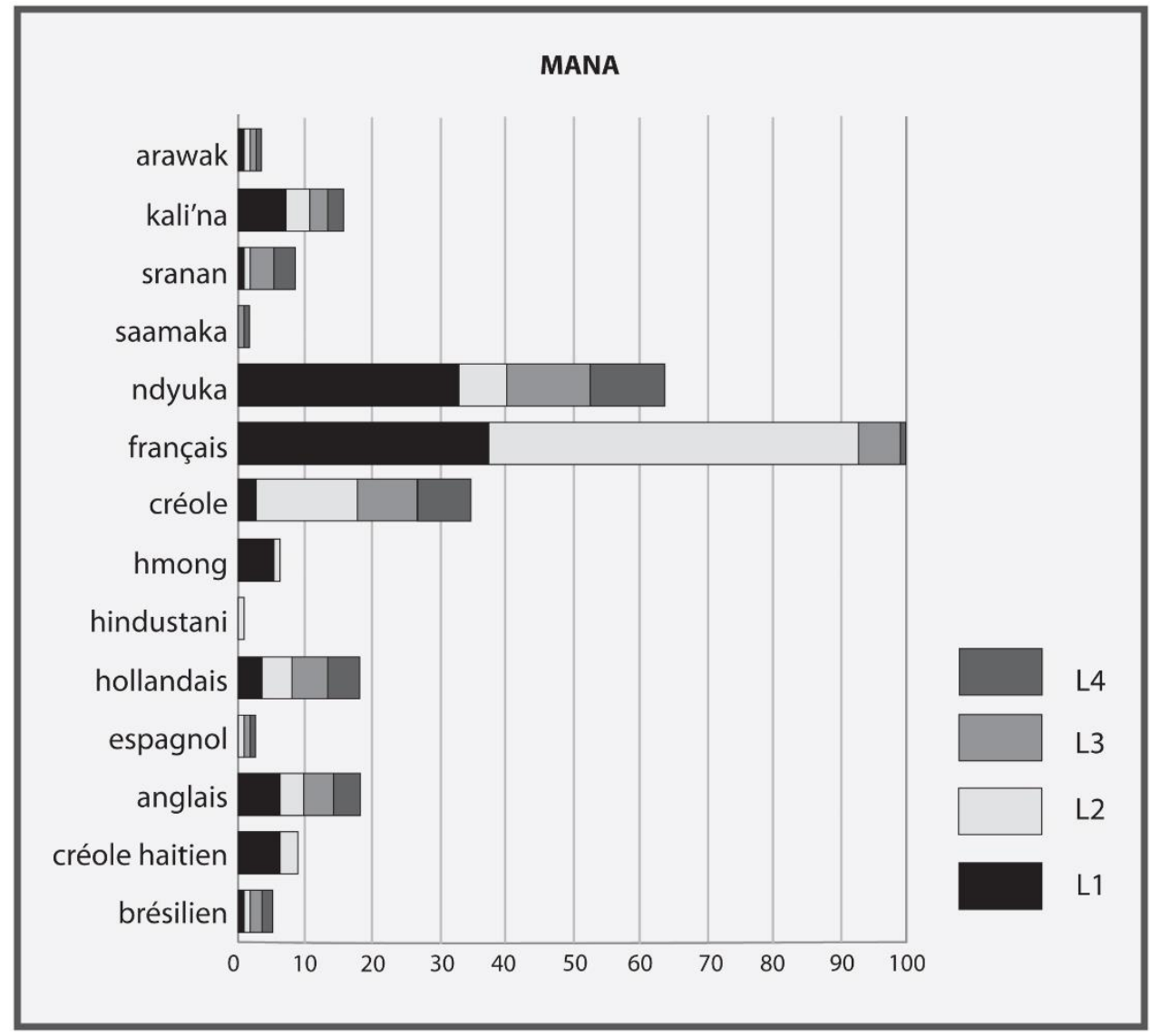

Figure 3: Languages reported in children's repertoires (results for Mana, French Guiana)

Sranantongo's place in children's language repertoires is somewhat different in the border area than in the two countries. Although widely used in Suriname, it often only appears as an L3 (about $60 \%$ in Moengo and Albina) with Dutch as L2 ${ }^{5}$. This suggests that both dominant Surinamese languages are salient but children more heavily

\footnotetext{
${ }^{5}$ Many children did not initially mention Sranantongo but had to be prompted (So do you also speak Sranantongo?). Children generally replied positively (of course) and expressed surprise at being asked.
} 
Isabelle Léglise \& Bettina Migge (2019): Language and identity construction on the French Guiana-Suriname border, International Journal of Multilingualism, DOI:10.1080/14790718.2019.1633332

invest in Dutch. Some children asserted that they consider Dutch rather than Sranantongo to be a more intrinsic part of their language identity. This demonstrates that children are invested in the nationally promoted, official Suriname identity. On the French side, Sranantongo has a greater presence $-15 \%$ mainly as an additional language - than in all of French Guiana where it represents less than $8 \%$ of the linguistic repertoires which, based on observation, is well below adult's actual usage in western French Guiana.

The results from the school surveys demonstrate that the indexical relationships that exist and are promoted between place, identity and language at the level of the two nations are present in the border zone and are reflected in children's reporting of language use as active family language transmissions practices and policies. They are, however, overall less prominent than in the rest of the two countries. The surveys also revealed ample evidence for the importance of ethnically-defined local languages in the border zone that are not promoted nationally. In the next section we explore whether the officially promoted indexical links are leaky and the existence of alternative identities exist.

\section{Alternative identifications in the border zone}

To examine evidence for the existence of distinctive language and identity indexical links in the border zone we first discuss the place of Maroon languages in children's linguistic repertoires and their language naming practices based on the school survey results as examples of self-identification. We then examine multilingual practices as iconic alternative identifications.

\subsection{The place of Maroon languages in children's linguistic repertoires}


Isabelle Léglise \& Bettina Migge (2019): Language and identity construction on the French Guiana-Suriname border, International Journal of Multilingualism, DOI:10.1080/14790718.2019.1633332

Many children in the border zone reported speaking Maroon languages as L1s or as having them in their repertoire. They declared using them in a range of social domains involving various interlocutors, indicating that they are practiced at home and for some also acquired and used as additional languages among friends for example. This difference between the national and border zone figures suggests the existence of language ideologies, family language policies and social conditions that promote the continued transmission and use of local languages in the face of considerable official and social pressure to be competent in the respective official languages. They contrast with those pursued by middle class people in the two capitals and other urban areas. We now explore the indexicalities involving the Maroon languages in more detail.

Given their prominence in children's repertoires, it could be argued that the mere fact of reporting their use establishes an indexical link to a third social entity, such as possibly the border zone. However, in the interviews the children never articulated such a place-based identity. Instead, children linked Maroon languages primarily to family or ethnically defined relationships. This corresponds with the traditional emic conceptualisation which establishes a natural link between (specific) language practices and membership in one of the established Maroon communities, e.g. Aluku, Ndyuka, Pamaka, Saamaka; membership depends on parents' and the mother's community origin in particular. Lack of such a correspondence is traditionally seen as lack of investment in one’s birth community (Migge \& Léglise 2013: 127-8).

Maroon children also have positive language attitudes towards their competence in these languages (Migge \& Léglise 2015: 94). Children who declare a Maroon language in their repertoire also did not voice negative assessments suggesting that they 
Isabelle Léglise \& Bettina Migge (2019): Language and identity construction on the French Guiana-Suriname border, International Journal of Multilingualism, DOI:10.1080/14790718.2019.1633332

have not internalised persistent negative attitudes towards them in the two national societies.

\section{2. Children's language naming practices}

When referring to the Maroon languages, children used traditional ethnic language names and umbrella terms. The latter are more recent creations that emerged in contact with non-Maroons and appear to have different indexicalities. In the local emic traditional ideology, every Maroon group is an independent nation (nasi) which has its own language, government and territory. ${ }^{6}$ While there is intermarriage and recognition of similarities that oppose them as a group to Europeans, Amerindians and other African-descent populations in the region, each group also strongly insists on its uniqueness. Linguistic difference plays a crucial role in this differentiation process (Migge \& Léglise 2013: 123ff). The school surveys show the following differences in the border zone.

On the French Guianese side, children frequently used language cum ethnic identifiers when naming the Maroon languages and also showed a strong preference for the locally used indigenous names. Thus, instead of using the names employed in French discourses, e.g. Boni, Paramaka and Saramaka, they used the local forms, e.g. Aluku, Pamaka and Saamaka. This indicates that the traditional Maroon ideology, which asserts intra-Maroon differences and the salience of Maroon identities, is still salient for French Guianese Maroon children.

\footnotetext{
${ }^{6}$ They freed themselves from European submission, follow similar socio-cultural and socio-religious practices and speak related languages.
} 
Isabelle Léglise \& Bettina Migge (2019): Language and identity construction on the French Guiana-Suriname border, International Journal of Multilingualism, DOI:10.1080/14790718.2019.1633332

On the Surinamese side, children also appear to assert intra-Maroon differences through their use of language names. However, they typically made use of Dutch terms such as Saramaccaans, Paramaccaans and Aucaans, ${ }^{7}$ rather than the local labels used in their languages and persisted in their use of Dutch-based terms when the interviewer used the latter terms. This is suggestive of an orientation to the dominant language ideology which emphasises the use of Dutch at the expense of local languages in such contexts.

Surinamese children mainly used Aucaans and Saramaccans and the names of the smaller communities had an unusually low frequency. There is evidence to suggest that children's language naming practices are strategic. Some children said they speak Aucaans at home, which traditionally asserts membership in the largest Eastern Maroon community locally called Ndyuka. However, in response to a question such as 'In which language(s) does your mother speak to you?', some responded 'Paramaccans' or 'Ndyuka' which index either the Pamaka or the Ndyuka Maroon community. However, they denied speaking Paramaccans or Ndyuka themselves explaining: 'No, I do not live in the village' or 'The people in the village speak it'. We take this to indicate that they use Aucaans to signal membership in an urban community. Thus, Aucaans foregrounds notions of urban-ness (or non-ruralness) and (Eastern) Maroon-ness but is underspecified for traditional intra-Maroon distinctions. This indicates the development of a pan-(Eastern) Maroon identity which might explain some children's assertion that 'It is all the same.' in response to questions about ethnic belonging.

\footnotetext{
${ }^{7} \mathrm{We}$ follow current Surinamese orthographic practice but there is variation.
} 
Isabelle Léglise \& Bettina Migge (2019): Language and identity construction on the French Guiana-Suriname border, International Journal of Multilingualism, DOI:10.1080/14790718.2019.1633332

Children from the French Guianese border zone employed different umbrella terms. Although Maroons traditionally do not use the outsider term Takitaki to refer to their languages because it is derogatory (Queixalos 2000) as it means 'chattering', children used this term in various strategic ways. They used it as a tool for identity management such as when accommodating non-Maroons, indicating lack of willingness to align with a specific community or when referring to an urban Maroon identity. Other children used the term Businenge(e) Tongo, an indigenous term introduced at the regional council in the 1990's to refer to Maroons (Businenge(e)) and their languages. Like Aucaans in the Surinamese border zone usage, Takitaki and Businenge(e) Tongo transcend traditional intra-Maroon divisions and assert a Maroon-ness associated with urban-ness and delinked from traditional ethnic categories and are thus indicative of a pan-Maroon identity.

The emergence of pan-Maroon identifications that exist side-by-side with national and ethnic identifications is probably due to the changed social reality of many children. Instead of living in the mostly mono-ethnic, extended family-based village communities of many of their parents and grandparents, children in the border zone currently grow up in multi-ethnic settings where they frequently 'face' members of other ethnic communities who also assert separate identities through the use of specific languages and cultural practices. In this context characterised by visible and audible differences supported by stereotyping discourses, the salience of intra-Maroon differences shrinks, allowing Maroons to converge on their extensive similarities. Given their numerical dominance in the region, emphasis of their similarities also has the added benefit of allowing them, particularly those who are members of smaller or traditionally stigmatised Maroon communities, to assert a powerful identity. In 
Isabelle Léglise \& Bettina Migge (2019): Language and identity construction on the French Guiana-Suriname border, International Journal of Multilingualism, DOI:10.1080/14790718.2019.1633332

discourses comparing people from different local communities, younger men in SaintLaurent-du-Maroni, for instance, often assert that Maroons are unique; they are much more enduring when it comes to physical labour, more stylish when it comes to clothes and do not allow themselves to be dominated in the same way as members of other local communities.

\subsection{Multilingual practices}

In order to determine whether there are linguistically unique practices in the border zone, we analysed our recordings. One aspect that emerged as particularly conspicuous in the border zone is the use of heterogeneous multilingual practices. In the traditional ideology, other languages, specifically Sranantongo and European languages, are reserved for interactions with non-Maroons and the main users of non-Maroon practices are Maroon men as they engage with the outside world. The use of other languages in interactions among Maroons is traditionally seen as problematic (Migge 2007). With growing integration into the coastal mainstream societies, the linguistic repertoires of all Maroons have expanded in step with their degree of contact with other local communities. Children are nowadays generally able to communicate in a European language. This is not the case for middle-aged and older people. (Younger) Maroons are also learning Brazilian Portuguese, Guyanese English and Creole, French Creoles due to their speakers' presence in the border zone and their presence in popular culture (Jamaican). This expansion of people's linguistic repertoires has resulted in greater use of non-Maroon languages as linguistic resources in interactions among Maroons.

There are close similarities in the social distribution of multilingual practices on both sides of the border. First, multilingual practices are more frequently used among 
Isabelle Léglise \& Bettina Migge (2019): Language and identity construction on the French Guiana-Suriname border, International Journal of Multilingualism, DOI:10.1080/14790718.2019.1633332

younger people and particularly young(er) men who grew up in the urban centres. Second, while multilingual practices have become commonplace and conventionalised across the whole range of interactional contexts for young(er) people, members of earlier generations (like village dwellers), tend to alternate between multilingual and monolingual practices; multilingual practices tend to be restricted to (urban) public, informal and emotionally charged situations and monolingual practices are used in facesensitive contexts, such as interactions with in-laws, elders, formal requests, local formal events etc. Third, multilingual practices have a different functionality among younger people in the border area. While earlier generations strategically employ them to mitigate the hierarchical nature of their social relationships, younger people use them as their regular mode of interaction; younger people, especially men, who employ monolingual practices in public everyday interactions are likely to be mocked for behaving like a villager (Migge 2007: 65-6).

Extract (1) is one example of younger people's multilingual practices. It is an extended turn from a meeting of members of a cultural organisation in Saint-Laurentdu-Maroni. The meeting took place in the yard of one of the members and assessed the achievements and problems the organisation encountered during the previous year. Ten people of Pamaka origin attended the meeting. The main speaker participants were in their thirties, had spent their childhood in the traditional villages and their youth first in urban Suriname and then in the French Guianese border area. The person who speaks in Extract (1) works in the broad area of intercultural mediation and sees his participation in the organisation as a way to enhance his profile. He speaks Pamaka, is reasonably fluent in French and also has a good knowledge of Dutch and Sranantongo. In other 
Isabelle Léglise \& Bettina Migge (2019): Language and identity construction on the French Guiana-Suriname border, International Journal of Multilingualism, DOI:10.1080/14790718.2019.1633332

contexts, he has asserted the importance of knowing many languages in order to get on in life.

Extract (1) yunkuman kuutu

B: Ini a pisi toli $\underline{\text { san }} \mathbf{u}$ taki fu a án serjusu fu u án libisama. A ini a pisi ape, mi o taki, mi o piki oo! Te yu nanga u án man e wooko ma a de ini i konde oo, da i mu luku a wooko fini.

Efu i lobi a waka dati u án, da i o gwe go namo na a wooko. Di i sabi di i no sabi, i o gwe go na a wroko omdat i wani teki a wooko, a de a ini i sikin. Dati u, a ini a dey di i

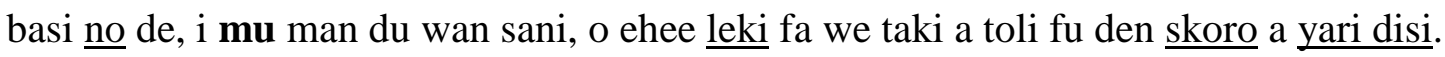
A yari san psa, $\mathbf{u}$ luku a yari disi. $\mathbf{U}$ akisi kon fu go ㅆini wan skoro ma omdat a pamplia fu organisasi no be herken door lanti pe den man fu éducation nationale musu stort a moni gi u. Den no man sabi pe den mu stort en gi i pe a sama meki a poking fu [A], mi án be abi en. Den naki ana gi en klopklop, a man ne en nen a e meki kaba. Dus na so a dansi de, na so wan grupa de, na so wan libi mu de. Kwolon! Mi ná e taki moo.

'In this story that we're talking about if it isn't serious then we're not humans. I will say something about this part, I will respond! If you and us cannot work together. but it [the event] takes place in your village, then you have to consider the matter carefully. If you like that kind of journey, we don't, then you'll definitely go and take up the job. Even if you don't know [the job], you'll take up the job because you want to have the job, it is your desire. That we, the day that your boss won't be there, you'll have to be able to do something. Ahm yes, like we were talking about the schools this year. Last year, we contemplated this year. We asked to go to a school, but because the organisation had 
Isabelle Léglise \& Bettina Migge (2019): Language and identity construction on the French Guiana-Suriname border, International Journal of Multilingualism, DOI:10.1080/14790718.2019.1633332

not been officially recognised by the government where the people of the ministry of education must hold the money for us. They don't know where they should hold it for you, where the person makes the attempt for [the cultural group], I did not have it. They clapped for him, the guy, he's already made a name for himself. Thus that's what the dance is like,' 'such a group exists, that's how life should be. Finish! I am not saying anything else.'

Extract (1) is remarkable in several ways. First, although this formal context traditionally calls for monolingual Pamaka, the speaker frequently alternates between Eastern Maroon forms (bold), Sranantongo (underlined), shared Eastern Maroon and Sranantongo forms (regular) and Dutch and French forms (italics). Second, although Pamaka generally serves as the main means of interaction in such contexts, multilingual alternation is so dense in places that at times it is not clear whether he uses a single language frame or a system that transcends Sranantongo and an Eastern Maroon variety (Migge 2015), playing with language boundaries in order to perform fuzziness and modernity (Léglise 2017). Third, each instance of alternation does not contextualise a particular interactional meaning in this context. Instead, it is the overall pattern that carries significance (Auer 2005). It signals a departure from traditional monolingual norms in this context. Such (poly)languaging (Jørgensen et al 2011) also allows the speaker to display his multilingual competence and to present himself as someone who is knowledgeable and in tune with the requirements of modern urban life - a natural leader in the current context. Finally, it projects an aura of modernity and critical distance to traditional Maroon society. 
Isabelle Léglise \& Bettina Migge (2019): Language and identity construction on the French Guiana-Suriname border, International Journal of Multilingualism, DOI:10.1080/14790718.2019.1633332

This brief discussion of language practices suggests that new modes of speaking are emerging in the urban context and border area. These practices emphasise the importance of Maroon-ness while at the same time bringing them into contact with linguistic elements that are iconic of urban-ness. Despite having been part of Maroon linguistic repertoires for a while, they are now normalising in that they are no longer viewed exclusively as subcultural practices. They are also expanding in that they are used in a wider range of social domains and by a greater range of people.

\section{Conclusion}

Our discussion argues that there is some evidence in favour of the impact of national language ideologies on the reporting of language use and on language ideologies in the border zone between French Guiana and Suriname. For example, children in the Surinamese part of the border zone did not strongly align with Sranantongo and employed Dutch instead of indigenous language names to refer to local languages; both practices are in line with national trends. This suggests that national language ideologies which index membership in the national community to a particular ex-colonial European language impact reporting of language use in the border zone. This impact was found to be stronger on the Surinamese side than on the French Guianese side.

More importantly, however, the analysis demonstrated the salience of alternative language and identity indexical ties in the border zone as a whole. Children are mostly socialised there through a local language, generally their parents' language of primary socialisation and often only 'discover' the ex-colonial European languages at school. This indicates that national language ideologies are less prominent and effective in the border zone. Children's survey responses also support the continued salience of ethnic 
Isabelle Léglise \& Bettina Migge (2019): Language and identity construction on the French Guiana-Suriname border, International Journal of Multilingualism, DOI:10.1080/14790718.2019.1633332

and the emergence of pan-Maroon identities. Evidence in support of the salience of a pan-Maroon identity is somewhat stronger in the Surinamese part and evidence for the salience of ethnic identities is stronger in the French Guianese part. New notions of Maroon-ness are emerging that link it to urban-ness and de-emphasise intra-Maroon differences. This new notion of Maroon-ness appears to also be accompanied by a rise in multilingual language practices.

The differences that emerged between the two parts of the border zone are rooted in the separate socio-historical developments, ideologies and national identities of the two national societies. Suriname has developed a widely accepted post-colonial identity while ethnic identification in French Guiana is still a primary means of identity projection apart from citizenship, but things are of course more complex. Language use and aspects of the language naming practices result from the renegotiation of symbolic boundaries; they redraw traditional ethnic boundaries and existing national boundaries. They are disseminated through the regular and frequent social, cultural and economic interactions between people in the border zone. The findings support a layered and dynamic perspective of community identity that is as much subject to bureaucratic boundary-making categories as it is to local or emic distinctions.

Our analysis focused on three different levels or entangled sociolinguistic scales (Blommaert 2007): national, regional and community. From a national and macro perspective, the border zone is distinct from the two national territories as people report different linguistic repertoires and display partially different language practices. In the border zone, we see evidence of convergence and divergence, though the former appears stronger. This suggests that both transnationalism and the development of a sense of political and social separateness and otherness (Martinez 1994) have shaped 
Isabelle Léglise \& Bettina Migge (2019): Language and identity construction on the French Guiana-Suriname border, International Journal of Multilingualism, DOI:10.1080/14790718.2019.1633332

the French Guiana-Suriname ‘borderlands milieu'. According to Llamas (2010: 228), 'the feeling of being culturally different from the core of majority populations in their 'national societies' has led the 'borderlanders' to develop and maintain 'shared values, ideas, customs and traditions with their counterparts across the borderline.' However, emergence or maintenance of similarities on some levels does not preclude sharp differences on other levels because multiple identities co-exist. They may include contradictory affiliations in the continuous process of self-identification and differentiation. This contributes in important ways to the making and unmaking of social and ethnic groupings. Border zones, as hybrid or interstitial spaces (Babha 1994), illustrate how contradictory discourses from various social actors and perspectives simultaneously overlap on one and several scales at the same time.

Our research suggests that multilingual border zones are particularly dynamic and hybrid zones that are best investigated using a mixed method approach. A logical next step is to examine how transnational families conceptualise multiple affiliations and multiple citizenships.

\section{References}

Agha, Asif. 2005. Registers of Language. In A Companion to Linguistic Anthropology, Alessandro Duranti (ed.), 23-45. Malden: Blackwell Publishing.

Auer, Peter.2005. A postscript: Code-switching and social identity. Journal of Pragmatics 37(3). 403-410.

Austin, Peter and Sallabank, Julia (eds.). 2014. Endangered Languages: Beliefs and Ideologies in Language Documentation and Revitalization. Oxford: Oxford University Press. 
Isabelle Léglise \& Bettina Migge (2019): Language and identity construction on the French Guiana-Suriname border, International Journal of Multilingualism, DOI:10.1080/14790718.2019.1633332

Balibar, Etienne. 1997. La crainte des masses. Politique et philosophie avant et après Marx. Paris: Galilée.

Bhabha, Homi. 1994. The Location of Culture. London/New York: Routledge.

Bourdieu, Pierre. 1991. Language and symbolic power. Cambridge, Polity Press.

Blommaert, Jan. 2007. Sociolinguistic scales. Intercultural Pragmatics 4 (1): 1-19.

Bucholtz, Mary and Hall, Kira. 2010. Locating identity in language. In Language and identities, Carmen Llamas and Dominic Watt (eds.), 18-28. Edinburgh: Edinburgh University Press.

Busch, Brigitta, and Kelly-Holmes, Helen. 2004. Language Boundaries as social, political, and discursive constructs. In Language, discourse and borders in the Yugoslav successor states, Brigitta Busch and Helen Kelly-Holmes (eds.), 1-12. Clevedon Buffalo Toronto: Multilingual Matters.

Carlin, Eithne. 2001. Of Riches and Rhetoric. In 20 th century Suriname: continuities and discontinuities in a New World society, Rosemarijn Hoefte and Pter Meel (eds.), 220-243. KITLV: Leiden.

Carlin, Eithne, Léglise, Isabelle, Migge, Bettina and Tjon Sie Fat, Paul (eds.) 2015. In and out of Suriname: Language, mobility, identity. Leiden/Boston: Brill.

Eckert, Penny. 2018. Meaning and Linguistics Variation: The Third Wave in Sociolinguistics. Cambridge: Cambridge University Press.

Greco, Luca and Auzanneau, Michelle. 2018. Dessiner les frontières. Lyon: ENS Editions.

Hoogbergen, Wim. 1990. The history of the Suriname Maroons. In Resistance and rebellion in Suriname: old and new, Gary Barna Shute (ed.), 65-102. Williamsburg: The College of William and Mary. 
Isabelle Léglise \& Bettina Migge (2019): Language and identity construction on the French Guiana-Suriname border, International Journal of Multilingualism, DOI:10.1080/14790718.2019.1633332

Irvine, Judith T. 1989. When Talk Isn't Cheap: Language and Political Economy. American Ethnologist 16 (2): 248-67.

Irvine, Judith T. and Gal, Susan. 2000. Language ideology and linguistic differentiation. In Paul Kroskrity (ed.) Regimes of language: Ideologies, polities, and identities, 3584. Santa Fe: School of American Research Press and James Currey.

Jørgensen J. Normann, Karrebaek, Martha Sif, Madsen, Lian Malai and Møller, Janus Spindler. 2011. Polylanguaging in Superdiversity, Diversities, 13(2), 23-37. [www.unesco.org/shs/diversities/vol13/issue2/art2] (10/4/17)

Jaffe, Alexandra. 2009. Stance: Sociolinguistic Perspectives. Oxford Studies in Sociolinguistics. Oxford, New York: Oxford University Press.

Jolivet, Marie-José. 2007. Approche anthropologique du multiculturalisme guyanais. Marrons et Créoles dans l'Ouest. In Pratiques et représentations linguistiques en Guyane: regards croisés, Isabelle Léglise and Bettina Migge (eds.), 87-106. Paris: Editions IRD.

Joseph, John. 2004. Language and identity. National, ethnic, religious.

Basingstoke/New York: Palgrave Macmillan.

Léglise, Isabelle. 2005. Contacts de créoles à Mana (Guyane française): répertoires, pratiques, attitudes et gestion du plurilinguisme. Etudes créoles 28 (1): 23-57.

Léglise, Isabelle. 2007. Des langues, des domaines, des régions. Pratiques, variations, attitudes en Guyane. In Pratiques et attitudes linguistiques en Guyane. Regards croisés. Léglise, Isabelle \& Bettina Migge (eds). Paris: IRD Editions, 29-47. Léglise, Isabelle. 2017. Multilingualism and heterogeneous language practices: new research areas and issues in the Global South, Langage et Société 160-161, 251-266. 
Isabelle Léglise \& Bettina Migge (2019): Language and identity construction on the French Guiana-Suriname border, International Journal of Multilingualism, DOI:10.1080/14790718.2019.1633332

Léglise, Isabelle and Migge, Bettina. 2015. Language Practices and Language Ideologies in Suriname: Results from a School Survey. In Carlin et al (eds.), 13-57. Amsterdam: Brill.

Llamas, Carmen. 2010. Convergence and divergence across a national border. In Language and identities, Carmen Llamas and Dominic Watt (eds.), 227-236. Edinburgh: Edinburgh University Press.

Martinez, Oscar. 1994. Border People. Tucson, AZ: University of Arizona Press. Migge, Bettina. 2007. Codeswitching and Social Identities in the Eastern Maroon community of Suriname and French Guiana. Journal of Sociolinguistics 11 (1): 5372.

Migge, Bettina. 2015. The role of discursive information in analyzing multilingual practices. In Code-Switching between structural and sociolinguistic perspectives, Kofi Yakpo and Gerald Stell, 185-206. Berlin: Mouton de Gruyter.

Migge, Bettina and Léglise, Isabelle. 2013. Exploring Language in a Multilingual Context: Variation, Interaction and Ideology in language documentation. Cambridge: Cambridge University Press.

Migge, Bettina and Léglise, Isabelle. 2015. Assessing the sociolinguistic situation of the Maroon Creoles. Journal of Pidgin and Creole Languages, 30 (1): 63-115.

Newman, David \& Paasi, Anssi. 1998. Fences and neighbours in the postmodern world: boundary narratives in political geography. Progress in Human Geography 22 (2): 186-207.

Ochs, Elinor. 1992. Indexing gender. In Rethinking context: Languages as an interactive phenomenon, Majory Goodwin \& Alessandro Duranti (eds.), pp. 335-358. Cambridge: Cambridge University Press. 
Isabelle Léglise \& Bettina Migge (2019): Language and identity construction on the French Guiana-Suriname border, International Journal of Multilingualism, DOI:10.1080/14790718.2019.1633332

Omoniyi, Tope. 2004. The sociolinguistics of Borderlands. Trenton NJ: Africa World Press, Inc.

Preece, Siân (ed). 2016. The Routledge Handbook of Language and Identity. Routledge: London.

Price, Richard and Price, Sally. 2003. Les Marrons. Chateauneuf-le-Rouge France: Vents d'ailleurs.

Price, Richard. 2018. Maroons in Guyane: Getting the Numbers Right. New West Indian Guide 92 (3-4): 275-83.

Queixalós, Francisco. 2000. Les langues de Guyane. In As linguas amazonicas hoje, Francisco Queixalós and Odile Renault-Lescure (eds.), 299-306. Sao Paulo: IRDISA-MPEG.

Renard, Jean-Pierre and Picouët, Patrick. 2007. Les frontières mondiales, origines et dynamiques. Nantes, Editions du temps.

Stell, Gerald. 2018. Sociolinguistic indexicalities in Ethnic Diversity: Perceptions of Ethnicity and Language in Suriname. New West Indian Guide 92: 35-61.

Urciuoli, Bonnie. 1995. Language and Borders. Annual Review of Anthropology 24: $525-546$.

Van Stiprian, Alex. 2015 Maroons and the communications revolution in Suriname's interior. In Carlin et al. (eds), 139-163. Leiden/Boston: Brill.

Yakpo, Kofi, van den Berg, Margot and Borges, Robert. 2015. On the linguistic consequences of language contact in Suriname: The case of convergence. In Carlin et al. (eds), 164-195. Leiden/Boston: Brill. 